\title{
BANTUAN HUKUM BAGI TERDAKWA TINDAK PIDANA DIBIDANG PERTAMBANGAN PADA TAHAP PENUNTUTAN
}

\author{
Himawan S. \\ Kejaksaan Negeri Kasongan \\ Komplek Pemda Katingan, Kasongan Kab. Katingan \\ Email: setiantohimawan@yahoo.com
}

\begin{abstract}
The purpose of the legal aid policy is a guarantee for the fulfillment of the rights of the poor to gain access to justice, both within and outside the judicial process; realizing the constitutional rights of citizens in accordance with the principle of equality before the law: ensuring sound implementation of legal aid implemented evenly across the region the Republic of Indonesia, and realize justice effective, efficient and accountable. This paper aims to empirically analyze which led to the implementation of legal aid to the accused of criminal offenses in the field of mining on the stage of prosecution, in the jurisdiction Katingan which is not run in accordance with the provisions of law (Criminal Procedure Code) mean while the legal implications for the defendant's criminal acts criminal offenses in the field of mining to not accompanied by legal counsel at this stage of the prosecution. This paper uses socio-juridical approach (empirical research). The results of this study indicate that in jurisdictions Katingan was 100 $\%$ of respondents claimed not accompanied by legal counsel. In the absence of assistance by a lawyer or legal aid lawyers who assist the defendant in the prosecution stage, the effect on the defendant is that the defendant 's rights in obtaining legal aid does not exist or nor available, that would be detrimental to the rights of the accused.
\end{abstract}

Key words: legal aid, defendant, criminal offense, prosecution

\begin{abstract}
Abstrak
Tujuan penyusunan kebijakan bantuan hukum merupakan jaminan terpenuhinya hak bagi fakir miskin untuk mendapatkan akses keadilan, baik di dalam maupun di luar proses peradilan; mewujudkan hak konstitusional warga negara sesuai dengan prinsip persamaan di hadapan hukum menjamin kepastian penyelenggaraan bantuan hukum dilaksanakan secara merata di seluruh wilayah Negara Republik Indonesia; dan mewujudkan peradilan yang efektif, efisien, dan dapat dipertanggungjawabkan. Tulisan ini bertujuan untuk menganalisis secara empiris yang menyebabkan pelaksanaan bantuan hukum bagi terdakwa tindak pidana di bidang pertambangan pada tahap penuntutan di wilayah hukum Kabupaten Katingan tidak berjalan sesuai dengan ketentuan perundang-undangan (KUHAP) serta implikasi hukum bagi terdakwa tindak pidana di bidang tindak pidana pertambangan yang tidak didampingi penasihat hukum pada tahap penuntutan. Tulisan ini menggunakan metode pendekatan yuridis sosiologis (penelitian empiris). Hasil penelitian ini menunjukkan bahwa di wilayah hukum Kabupaten Katingan ternyata $100 \%$ responden mengaku tidak didampingi penasehat hukum. Dengan tidak adanya pendampingan bantuan hukum oleh pengacara atau advokat yang mendampingi terdakwa dalam tahap penuntutan, pengaruhnya bagi terdakwa adalah bahwa hak-hak terdakwa dalam memperoleh bantuan hukum tidak ada atau tidak didapatkan, sehingga akan merugikan hak-hak terdakwa.
\end{abstract}

Kata kunci: bantuan hukum, terdakwa, tindak pidana, penuntutan 


\section{Latar Belakang}

Miranda Rule tepatnya Miranda

Priciple,${ }^{1}$ merupakan hak-hak konstitusional dari terdakwa yang bersifat universal dihampir semua negara yang berdasarkan atas hukum.

Indonesia sebagai negara yang berdasarkan atas hukum pada dasarnya sangat menghormati Miranda Principle ini. Komitmennya Indonesia terhadap penghormatan Miranda Principle telah dibuktikan dengan mengadopsi Miranda Principle ini ke dalam sistem Hukum Acara Pidana (KUHAP). Secara universal Miranda Principle merupakan hak-hak dasar manusia atau hak Konstitusional tersangka yang pada pokoknya meliputi:

1. Hak untuk tidak menjawab atau diam sebelum diperiksa dan/atau sebelum dilakukan penyidikan (a right to remain in silent);

2. Hak untuk menghadirkan penasihat hukum dan hak untuk berkonsultasi sebelum dilakukan pemeriksaan atau penyidikan oleh penyidik (a right to the presence of an attotney or the right to counsil);
3. Hak untuk disediakan penasihat hukum bagi tersangka atau terdakwa yang tidak mampu.

Di Indonesia keberadaan Miranda Principle telah diakomodir di dalam Pasal 54, 55, 56 ayat (1) dan Pasal 114 KUHAP. Tidak hanya di dalam KUHAP, akses keadilan sebagai wujud persamaan hak dihadapan hukum berupa pemberian bantuan hukum juga diatur dalam ketentuan-ketentuan tersebut di bawah ini:

1. Undang-Undang Dasar Negara Republik Indonesia 1945 (UUD NRI 1945); Hak atas bantuan hukum adalah bagian dari peradilan yang adil dalam prinsip negara hukum. $^{2}$ Konstitusi telah mengakui negara hukum seperti ditegaskan dalam Pasal 1 ayat (3) Perubahan Ketiga UUD NRI 1945. Sedangkan Pasal 27 ayat (1) dinyatakan, bahwa: "Segala warga negara bersamaan kedudukannya di dalam hukum dan pemerintahan dan wajib menjunjung hukum dan pemerintahan itu dengan tidak ada kecualinya". Persamaan di hadapan

1 Adapun Miranda Principle, dalam praktiknya dibagi menjadi 3 (tiga), yaitu: 1. Miranda Rule, yaitu suatu aturan yang mewajibkan polisi atau penyidik untuk memberikan hak-hak seseorang sebelum dilakukan pemeriksaan oleh penyidik antara lain hak untuk diam, karena segala sesuatu yang dikatakannya dapat digunakan untuk melawannya dan memberatkannya di Pengadilan; hak untuk menghubungi penasihat hukum/advokat, jika ia tidak mampu maka ia berhak untuk disediakan penasihat hukum oleh negara. 2. Miranda Right, adalah mirip dengan miranda rule, namun ditekankan disini tersangka pada hak untuk diam dan menolak menjawab segala pertanyaan polisi yang menangkap sebelum diperiksa oleh penyidik; hak untuk menghubungi penasihat hukum dan mendapat bantuan hukum dari advokat bersangkutan; hak untuk memilih penasihat hukumnya sendiri; dan hak untuk disediakan penasihat hukum jika tersangka "tidak mampu"; 3. Miranda Warning, adalah peringatan yang harus diberikan kepada tersangka akan hak-haknya sebagaimana yang terdapat di dalam Miranda Rule dan Miranda Right di atas, polisi tidak bisa mengintrogasi tersangka di tempat kejadian, kecuali menanyakan sebatas indentitas belaka. Jika dilakukan maka hasilnya tidak sah dan tidak bisa dijadikan bukti di Pengadilan.

2 Dalam negara hukum (rechtsstaat) negara mengakui dan melindungi hak asasi manusia setiap individu. Pengakuan negara terhadap hak individu ini tersirat di dalam persamaan kedudukan di hadapan hukum bagi semua orang. Dalam suatu negara hukum semua orang harus diperlakukan sama di hadapan hukum (equality before the law). Persamaan di hadapan hukum harus diimbangi juga dengan persamaan perlakuan (equal treatment). 
hukum tersebut dapat terealisasi dan dapat dinikmati oleh masyarakat apabila ada kesempatan yang sama untuk mendapatkan keadilan. Persamaan dihadapan hukum harus diiringi pula dengan berbagai kemudahan untuk mendapatkan keadilan, termasuk di dalamnya pemenuhan hak atas bantuan hukum.

2. Undang-undang Republik Indonesia Nomor 4 Tahun 2004 tentang Kekuasaan Kehakiman;

a. Pasal 13 ayat (1) tentang: Organisasi, administrasi, dan finansial Mahkamah Agung dan badan peradilan yang berada di bawah kekuasaan Mahkamah Agung.

b. Pasal 37 tentang: Setiap orang yang tersangkut perkara berhak memperloleh bantuan hukum.

3. Instruksi Menteri Kehakiman RI No. M 01-UM.08.10 Tahun 1996, tentang Petunjuk Pelaksanaan Program Bantuan Hukum Bagi Masyarakat Yang Kurang Mampu Melalui Lembaga Bantuan Hukum

4. Instruksi Menteri Kehakiman RI No. M 03-UM.06.02 Tahun 1999, tentang Petunjuk Pelaksanaan Program Bantuan Hukum Bagi Masyarakat Yang Kurang Mampu Melalui Pengadilan Negeri dan Pengadilan Tata Usaha Negara.

5. Surat Edaran Direktur Jenderal Badan Peradilan Umum dan Peradilan Tata Usaha Negara No. D.Um.08.10.10 tanggal 12 Mei 1998 tentang Petunjuk Pelaksanaan
Bantuan Hukum Bagi Golongan Masyarakat Yang Kurang Mampu Melalui Lembaga Bantuan Hukum (LBH).

Selanjutnya, pada tanggal 4 Oktober 2011, Dewan Perwakilan Rakyat (DPR) telah mengesahkan RUU Tentang Bantuan Hukum (RUU Bantuan Hukum) dalam rangka menjamin hak konstitusional bagi setiap warga negara yang mencakup perlindungan hukum, kepastian hukum, persamaan di depan hukum, dan perlindungan hak asasi manusia.

Dengan disahkannya Undang-undang Nomor 16 Tahun 2011 tentang Bantuan Hukum ini terdapat 2 (dua) makna, yaitu:

1. Melalui undang-undang ini setiap orang, khususnya warga negara yang tidak mampu berhak atas bantuan hukum dan negara bertanggungjawab memenuhi hak tersebut dengan menyediakan anggaran yang memadai. Hak atas bantuan hukum adalah hak dasar setiap warga negara yang sama kedudukannya dengan hak-hak lain seperti kesehatan, pekerjaan, sandang dan pangan, dan seterusnya.

2. Negara melalui Kementerian Hukum dan HAM bertanggungjawab mengelola program bantuan hukum secara akuntabel, sehingga implementasi program dapat dirasakan manfaatnya oleh masyarakat dengan menerima bantuan hukum yang profesional, bertanggungjawab dan memenuhi rasa keadilan para pencari keadilan. Dengan adanya program bantuan hukum diharapkan tidak akan terjadi lagi peristiwa salah tangkap, rekayasa kasus, 
ataupun perlakukan kekerasan selama proses penyidikan atau penyelidikan.

Fakta empiris menunjukkan bahwa tidak semua warga negara Indonesia menikmati fasilitas bantuan hukum tersebut. Mengingat besarnya jumlah penduduk Indonesia yang mencapai 220 juta jiwa serta jumlah penduduk miskin yang mencapai 32 juta jiwa serta wilayah Indonesia yang sedemikian luas, akses keadilan bagi mereka yang tergolong miskin atau tidak mampu masih jauh dari tingkat yang ideal. Secara kuantitatif, rasio antara advokat dan jumlah penduduk Indonesia saat ini masih sangat timpang.

Dalam hal ini khusus yang terjadi di Kasongan Kabupaten Katingan sangat memprihatinkan dalam hal bantuan hukum pada saat penuntutan, karena setiap dilakukan penuntutan, pembelaan yang dilakukan terdakwa hanyalah berdasarkan apa yang diperbuatnya, padahal banyak cara dan argumentasi agar terdakwa tersebut membela dirinya sendiri supaya keputusan hakim tidak berat sebelah, lain hal dengan seseorang narapidana yang didampingi penasehat hukum, dia masih bisa menceritakan titik terang permasalahannya dan penasehat hukumnya bisa memberikan yang menjadi dalih di depan persidangan yang meringankan keputusan hakim terhadapnya.

Secara umum fenomena bantuan hukum di Indonesia dengan melihat realitas yang ada juga tidak jauh berbeda sebagaimana terjadi di Kabupaten Katingan. Pada kasuskasus tertentu tidak jarang terdakwa tidak didampingi penasehat hukum, padahal secara aturan mereka berhak mendapatkan penasehat hukum untuk mendampinginya dalam menghadapi kasus tersebut.

Misalnya dalam kasus tindak pidana di bidang pertambangan yang ancaman pidana 5 tahun/lebih dan secara aturan mereka sudah seharusnya mendapatkan hak yang sesuai seperti yang di atur dalam KUHAP hak-hak terdakwa untuk mendapatkan pendampingan dari penasehat hukum. Namun fakta empiris memperlihatkan bahwa selama proses dan sampai pada putusan pengadilan mereka tidak memperoleh bantuan hukum berupa pendampingan penasehat hukum.

Hal inilah yang akan dibahas oleh penulis, di mana penulisakan menganalisa pelaksanaan hak bantuan hukum bagi terdakwa pelaku tindak pidana di bidang pertambangan dalam proses penuntutan di wilayah hukum Kabupaten Katingan serta pengaruh penerapan bantuan hukum tersebut bagi pelaksanaan pemenuhan hak-hak terdakwa dalam proses penuntutan.

\section{Pembahasan}

Konsep Negara Hukum Indonesia berbeda dengan konsep rechtstaat dan rule of law karena mempunyai latarbelakang yang berbeda pula. Konsep Negara Hukum Indonesia adalah sebagaimana disebutkan di dalam Pasal 1 ayat (3) Amandemen ketiga UUD NRI 1945 yang berbunyi: "Negara Indonesia adalah Negara Hukum".

Istilah negara hukum dalam kepustakaan 
Indonesia hampir selalu dipadankan dengan istilah-istilah asing antara lain rechts staat, atat de droit, the state according to law, legal state, dan rule of law. Notohamijdojo memadankan istilah negara hukum di dalam konstitusi Indonesia dengan konsep rechtsstaat sebagaimana dalam tulisannya “... negara hukum atau rechtsstaat". ${ }^{3}$ Di samping itu, Muhammad Yamin di dalam tulisannya menyebutkan bahwa “...Republik Indonesia ialah negara hukum (rechtsstaat, government of law)". ${ }^{4}$

Berbeda dengan pendapat di atas, menurut Philipus M. Hadjon yang lebih mengkritik terhadap para pakar hukum yang mempersamakan istilah negara hukum dengan konsep rechtstaat dan konsep the rule of law, dia menyatakan bahwa:

Di dalam sebuah nama terkandung isi (nomen est omen), negara hukum merupakan sebuah konsep tersendiri yang dipergunakan oleh negara Indonesia, sehingga tidak bisa dipadankan dengan konsep rechtsstaat atau konsep the rule of law yang telah mempunyai isi masing-masing yang berbeda. Pendapat ini tentu dapat difahami mengingat saat ini terdapat 5 (lima) konsep negara hukum yang dianggap berpengaruh dan telah mempunyai isi yang berlainan. Di antaranya: pertama, rechtsstaat yang merupakan konsep yang dikenal di Belanda; Kedua, the rule of law yang merupakan konsep yang di kenal di negara-negara Anglo-Saxon seperti Inggris, Amerika Serikat. ${ }^{5}$

\section{A. Indonesia sebagai Negara Hukum}

Negara berdasarkan hukum ditandai oleh beberapa asas, antara lain asas bahwa semua perbuatan atau tindakan pemerintahan atau negara harus didasarkan pada ketentuan hukum tertentu yang sudah ada sebelum perbuatan atau tindakan itu dilakukan. Campur tangan atas hak dan kebebasan seseorang atau kelompok masyarakat hanya dapat dilakukan berdasarkan aturan-aturan hukum tertentu. Asas ini lazim disebut asas legalitas (legaliteits beginsel). Untuk memungkinkan kepastian perwujudan asas legalitas ini, harus dibuat berbagai peraturan hukum antara lain peraturan perundang-undangan.

Selain salah satu asas yang telah disebutkan di atas Prajudi Atmosudirdjo menyebutkan bahwa asas-asas pokok negara hukum ada tiga, yakni: ${ }^{6}$

1. Asas monopoli paksa (Zwangmonopoli);

Monopoli penggunaan kekuasaan negara dan monopoli penggunaan paksaan untuk membuatorangmentaatiapayangmenjadi

3 Notohamidjojo, Makna Negara Hukum, Badan Penerbit Kristen, Jakarta, 1970, hlm. 27.

4 Muhammad Yamin, Proklamasi dan Konstitusi Indonesia, Ghalia Indonesia, Jakarta, 1982, hlm. 72.

5 Irfan Fachruddin, Op.cit., hlm. 110-111.

6 Ali Sadikin, Loc.cit. 
keputusan penguasa negara hanya berada di tangan pejabat penguasa negara yang berwenang dan berwajib untuk itu. Jadi siapapun yang lain dari yang berwenang/ berwajib dilarang, artinya barang siapa melakukan penggunaan kekuasaan negara dan menggunakan paksaan tanpa wewenang sebagaimana dimaksud di atas disebut "main hakim sendiri".

2. Asas persetujuan rakyat;

Orang (warga masyarakat) hanya wajib tunduk, dan dapat dipaksa untuk tunduk, kepada peraturan yang dicipta secara sah dengan persetujuan langsung (Undangundang Formal) atau tidak langsung (legislasi delegatif, peraturan atas kuasa undang-undang) dari Dewan Perwakilan Rakyat. Jadi bilamana ada peraturan (misalnya: mengadakan pungutan pembayaran atau "sumbangan wajib") yang tidak diperintahkan atau dikuasakan oleh undang-undang, maka peraturan itu tidak sah, dan hakim Pengadilan wajib membebaskan setiap orang yang dituntut oleh karena tidak mau menaatinya, dan bilamana Pejabat memaksakan peraturan tersebut, maka dia dapat dituntut sebagai penyalahgunaan kekuasaan negara, minimal digugat sebagai perkara "perbuatan penguasa yang melawan hukum".

3. Asas persekutuan

hukum (rechtsgemeenschap); Asas persekutuan hukum berarti, bahwa: Rakyat dan penguasa negara bersama-sama merupakan suatu persekutuan hukum (rechtsgemeenschap, legal partnership), sehingga para Pejabat Penguasa negara di dalam menjalankan tugas dan fungsi beserta menggunakan kekuasaan negara mereka tunduk kepada hukum (sama dengan Rakyat/warga masyarakat). Berarti baik para pejabat penguasa negara maupun para warga masyarakat berada di bawah dan tunduk kepada hukum (undang-undang) yang sama.

Syarat-syarat dasar rechtsstaat yang dikemukakan oleh Burkens, et.al., sebagaimana dikutip oleh Philipus M. Hadjon dalam tulisannya tentang Ide negara Hukum dalam Sistem Ketatanegaraan Indonesia adalah: ${ }^{7}$

1. Asas legalitas;

Setiap tindak pemerintahan harus didasarkan atas dasar peraturan perundang-undangan (wetterlikegrondslag). Dengan landasan ini Undang-undang formal dan Undangundang Dasar sendiri merupakan tumpuan dasar tindak pemerintahan. Dalam hubungan ini pembentuk undangundang merupakan bagian penting negara hukum;

2. Pembagian kekuasaan;

Syarat ini mengandung makna bahwa kekuasaan negara tidak boleh hanya bertumpu pada satu tangan; 
3. Hak-hak dasar (grondrechten);

Hak-hak dasar merupakan sasaran perlindungan hukum bagi rakyat dan sekaligus membatasi pembentukan undang-undang;

4. Pengawasan peradilan;

Bagi rakyat tersedia saluran melalui pengadilan yang bebas untuk menguji keabsahan tindakan pemerintahan (rechtmatigeidstoetsing).

Sebelum UUD 1945 diamandemen, dalam penjelasan mengenai Sistem Pemerintahan negara ditegaskan bahwa Indonesia adalah negara yang berdasar atas hukum (Rechtsstaat), tidak berdasarkan kekuasaan belaka (Machtsstaat). UUD 1945 (amandemen) menegaskan dalam Pasal 1 ayat (3) bahwa "negara Indonesia adalah negara hukum", hal ini mensyaratkan kepada seluruh penyelenggara negara dan warga negaranya harus taat terhadap hukum. UUD 1945 merupakan manifestasi dari konsep dan alam pikiran Bangsa Indonesia yang lazim disebut dengan Hukum Dasar Tertulis. UUD 1945 sebagai Hukum Dasar Tertulis, hanya memuat dan mengatur hal-hal yang prinsip dan garisgaris besar saja. Negara Indonesia sebagai negara hukum dapat dilihat pada:

1. Bab I Pasal 1 ayat (3) UUD 1945 Negara Indonesia adalah negara hukum;

2. Pembukaan dicantumkan kata-kata: Pemerintah negara Indonesia yang melindungi segenap bangsa Indonesia, dan seluruh tumpah darah Indonesia;
3. Bab X Pasal 27 ayat (1) disebutkan segala warga negara bersamaan kedudukannya di dalam hukum dan pemerintahan serta wajib menjunjung hukum dan pemerintahan itu dengan tidak ada kecualinya;

4. Penjelasan UUD 1945 yang sudah dihapus disebutkan dalam Sistem Pemerintahan negara, yang maknanya tetap bisa dipakai, yaitu Indonesia ialah negara yang berdasar atas hukum (rechtstaat), tidak berdasarkan atas kekuasaan belaka (Machtstaat);

5. Sumpah/janji Presiden/Wakil Presiden ada kata-kata "memegang teguh Undangundang Dasar dan segala undang-undang dan peraturannya dengan seluruslurusnya";

6. Bab XA Hak Asasi Manusia Pasal 28i ayat (5), disebutkan bahwa "Untuk penegakkan dan melindungi hak asasi manusia sesuai dengan prinsip negara hukum yang demokratis, maka pelaksanaan hak asasi manusia dijamin, diatur dan dituangkan dalam Peraturan Perundang-Undangan;

7. Sistem hukum yang bersifat nasional;

8. Hukum dasar yang tertulis (konstitusi), hukum dasar tak tertulis (konvensi);

9. Tap MPR No.III/MPR/2000 tentang Sumber Hukum dan Tata Urutan Peraturan Perundang-Undangan;

10. Adanya peradilan bebas.

Selanjutnya di dalam penyelenggaraan negara Indonesia sebagai negara hukum telah dikembangkan konsep checks and balances, seperti adanya Peradilan Tata Usaha Negara. 
Selain itu juga telah dikembangkan lembaga-lembaga ekstra struktural baik yang dibentuk berdasarkan Undang-undang maupun dengan Keputusan (Peraturan) Presiden tentang lembaga-lembaga yang bertugas untuk mengawasi jalannya pemerintah, seperti Mahkamah Konstitusi, Komisi Pemeriksa Korupsi, Komisi Ombudsmandan sebagainya. Lebih lanjut sebagai implementasi dari Tap MPR No. XI/MPR/1998 dalam upaya menciptakan good governance telah dikeluarkan Undang-undang Nomor 28 Tahun 1999 tentang Penyelenggaraan negara yang Bersih dan Bebas dari Korupsi, Kolusi dan Nepotisme, bahwa di dalam negara hukum dan penyelenggaraan negara harus mengacu kepada asas-asas umum penyelenggaraan negara.

Dari uraian di atas, dapatlah disimpulkan bahwa negara hukum adalah sebuah negara yang menjadikan hukum sebagai panglima dalam penyelenggaraan negara. Tentunya maksud hukum sebagai panglima tersebut diterapkan melalui pelaksaanaan prinsip-prinsip negara hukum. Indonesia sebagai negara hukum, maka segala sesuatu harus berdasarkan kepada hukum, yang diimplementasikan kepada Peraturan Perundang-undangan yang ada sebagai manifestasi dari hukum positif, dan dalam rangka penegakkan hukum telah dibentuk berbagai lembaga peradilan sebagai upaya untuk memberikan kepastian hukum dan melindungan hak-hak setiap warga negara Indonesia.

\section{B. Hak Asasi Manusia (HAM)}

Hak asasi adalah kebutuhan mendasar dari umat manusia, ia merupakan hak natural dan merupakan pemberian langsung dari Tuhan, oleh karena itu tidak satu seorang atau satu pihak pun yang bisa mengambilnya.

Dewasa ini, dunia tidak lagi memandang hak asasi manusia sekedar sebagai perwujudan paham individualisme dan liberalisme seperti dahulu. Hak asasi manusia lebih dipahami secara manusiawi sebagai hak-hak yang melekat dengan harkat dan hakikat kemanusian, apapun latar belakang ras, etnik, agama, warna kulit, jenis kelamin, usia atau pekerjaan.

Pemahaman yang lebih manusiawi itulah yang melatar belakangi konsep modern atau pengertian tentang hak asasi manusia, seperti berikut:

Human rights could generally be defined as those rights which are inherent in our nature and without which we cannot live as human beings. Artinya: secara umum hak asasi manusia dapat dirumuskan sebagai hak yang melekat dengan kodrat kita sebagai manusia yang bila tidak ada, mustahil kita akan dapat hidup sebagai manusia. ${ }^{8}$

Dengan pemahaman seperti itu, konsep

8 Safroedin Bahar, Hak Asasi Manusia, Pustaka Sinar Harapan, Jakarta, 1997, hlm. 6. 
hak asasi manusia disifatkan sebagai suatu "common standart of achievement for all peoples and all nations" yaitu sebagai tolok ukur bersama tentang prestasi kemanusiaan yang perlu dicapai oleh seluruh masyarakat dan seluruh bangsa di dunia. Menurut Douglas W. Cassel, "nilai-nilai hak asasi manusia adalah kebebasan, kesetaraan, otonomi dan keamanan. Lebih dari itu, inti nilai dari hak asasi manusia adalah martabat manusia". 9

Jack Donelly mengungkapkan pengertian hak asasi manusia secara harafiah, menurut beliau hak asasi manusia itu adalah "hak yang dimiliki oleh seseorang sekedar karena orang itu adalah manusia. Gagasan yang sepintas tampak sederhana ini memiliki akibat-akibat politik dan sosial yang mendalam". ${ }^{10}$

Hak asasi menurut konsep barat, secara formal dapat ditemui dalam deklarasi kemerdekaan 13 negara-negara Amerika Juli 1776, yaitu: “...we hold these truths to be selfevident; that all men are created equel; that they are endowed by their creator with certain inalienable rights, liberty and the pursuit of happiness". ${ }^{11}$ Pendukung dari konsep ini adalah John Locke yang selanjutnya dikembangkan oleh Lafayette ke dalam Declaration des droit de I'homme et du citoyen pada tahun 1789 di Paris. “...men are born and remain free and equel in rights; indeed, that the purpose of all political associations is the convervation of the natural and inalienable rights are liberty, property, security and resistance to oppression; liberty is defined as "being unrestrained in doing anything that does not interfere with another's rights", and is held to include the right to free speech, a free press, religion freedom, and freedom from arbitrary arrest ${ }^{\prime} .{ }^{12}$

Dari pernyataan tersebut, tampak bahwa mengedepankan hak asasi manusia merupakan reaksi keras terhadap sistem pemerintahan, politik, sosial sebelumnya yang bersifat absolut, yang seharusnya keberadaan negara (sebagai lembaga politik) untuk menjamin hak asasi manusia. Dengan demikian, hak-hak tersebut bersifat mutlak dan harus dijunjung tinggi oleh negara, pemerintah dan organisasi yang ada. Penghormatan hak-hak individu (kemerdekaan dan pemilikan), ada yang berpendapat merupakan satu kelemahan konsep barat yang individualistik.

Sehubungan dengan itu, persoalan hak asasi manusia hendaknya didekati secara komprehensif, dalam arti merupakan

9 Altidjo Alkostar, Pengadilan HAM Indonesia dan Peradaban, Pusham UII, Yogyakarta, 2004, hlm. 1.

10 Pendapat Jack Donelly dalam George Clark (Executive Editor), Hak Asasi Manusia Sebuah Pengantar, Pustaka Sinar Harapan, Jakarta, 1998, hlm. 2.

11 Masyhur Effendi, Hak Asasi Manusia dalam Hukum Nasional dan Internasional, Ghalia Indonesia, Jakarta, 1993, hlm. 18.

12 Ibid, hlm. 18-19. 
tanggung jawab bersama, baik penguasa, pemegang uang, pemikir, agamawan dan siapa saja yang merasa/mau terlibat dalam masalah kemanusiaan. Hal ini penting, karena masih banyak kelompok manusia yang kurang beruntung, baik karena berada pada posisi "bawah, golongan tak berpunya" yang kurang mendapatkan hak-haknya. Di sinilah perlu, pendekatan kontektual dalam melaksanakan hak asasinya.

Ajaran komunis yang menjanjikan penghapusan kelas dan perjuangan kelas bermaksud menghilangkan akar konflik sosial, karena itu hak asasi manusia yang diagung-agungkan ajaran liberalisme menjadi tidak penting. Hak asasi menjadi perlu dalam masyarakat kapitalisme. Dalam masyarakat komunis, yang penting konflik tidak akan ada dan juga tidak ada kelas. Dalam masyarakat komunis dapat menikmati hak asasi di bidang ekonomi yang dibutuhkan semua anggota masyarakat, dan diatur di bawah negara, kemandirian menjadi tabu. Dengan demikian, kehancuran ideologi komunis, sebagaimana terlihat dewasa ini, dari sudut ini dapat dimengerti, karena paham komunis meniadakan hak-hak individu, sehingga bertentangan dan menentang hukum alam (tidak memberi kesempatan kepada orang perorang untuk memiliki hak selama hidup yang diberi oleh Tuhan). Penegakan hak dalam hak asasi, justru karena sejak lahirnya manusia sudah memiliki hal tersebut. Dengan demikian, dalam ideologi komunis mentabuhkan adanya kelompok yang berbeda pendapat (oposisi), oposisi adalah lawan yang harus dihapuskan.

Hak asasi manusia adalah hak-hak yang dimiliki setiap manusia dan berhak dinikmatinya semata-mata karena ia adalah manusia. Pada konfrensi dunia tentang hak asasi manusia pada tahun 1993, berbagai negara menegaskan dalam Deklarasi Wina bahwa Hak Asasi Manusia adalah "hak yang dibawa oleh semua manusia sejak lahir dan bahwa perlindungan atas hak itu merupakan tanggungjawab pertama pemerintah".

Di Indonesia pengertian dari Hak Asasi Manusia dapat dilihat pada beberapa Peraturan Perundang-undangan, seperti dalam Undangundang RI Nomor 39 Tahun 1999 tentang Hak Asasi Manusia dan Undang-undang RI Nomor 26 Tahun 2000 tentang Pengadilan Hak Asasi Manusia. Kedua Undang-undang ini menjelaskan pengertian Hak Asasi Manusia, yakni:

Seperangkat hak yang melekat pada hakekat dan keberadaan manusia sebagai mahluk Tuhan Yang Maha Esa dan merupakan anugrah-Nya yang wajib dihormati, dijunjung tinggi, dan dilindungi oleh negara, hukum, pemerintah, dan setiap orang demi kehormatan serta perlindungan harkat dan martabat manusia.

Dari berbagai pendapat mengenai pengertian Hak Asasi Manusia di atas, dapat disimpulkan bahwa Hak Asasi Manusia adalah standar dasar yang merupakan anugrah 
Tuhan, yang tidak boleh dicabut siapa pun. Dan tanpanya, manusia tidak dapat hidup sesuai martabat atau fitrahnya sebagai manusia. Hak Asasi Manusia adalah landasan dari kebebasan, keadilan dan kedamaian. Hak Asasi Manusia mencakup semua yang dibutuhkan manusia untuk tetap menjadi manusia, dari segi kehidupan sipil, politik, ekonomi, sosial dan budaya.

\section{Sistem Peradilan Pidana}

Istilah Sistem Peradilan Pidana (SPP) atau dalam istilah Inggris-nya Criminal Justice System merupakan mekanisme kerja dalam penanggulangan kejahatan dengan mempergunakan dasar "pendekatan sistem ${ }^{13}$ ". Menurut Mardjono Reksodipoetro, menjelaskan bahwaSistem Peradilan Pidana adalah sistem pengendalian kejahatan yang terdiri dari lembaga-lembaga Kepolisian, Kejaksaan, Pengadilan dan Pemasyarakatan terpidana. Sedangkan tujuan Sistem Peradilan Pidana adalah: ${ }^{14}$

1. Mencegah masyarakat menjadi korban kejahatan;

2. Menyelesaikan kasus kejahatan yang terjadi sehingga masyarakat puas bahwa keadilan telah ditegakkan dan yang bersalah dipidana;

3. Mengusahakan agar mereka yang pernah melakukan kejahatan tidak mengulangi lagi kejahatannya.

Sedangkan menurut Muladi, tujuan Sistem Peradilan Pidana dapat dikategorikan sebagai berikut: ${ }^{15}$

1. Tujuan jangka pendek, apabila yang hendak dicapai resosialisasi dan rehabilitasi pelaku tindak pidana;

2. Tujuan jangka menengah, apabila yang hendak dicapai lebih luas yakni pengendalian dan pencegahan kejahatan dalam konteks politik kriminal (Criminal Policy);

3. Tujuan jangka panjang, apabila yang hendak dicapai adalah kesejahteraan masyarakat (social welfare) dalam konteks politik sosial (Social Policy).

Dalam Sistem Peradilan Pidana (SPP) di Indonesia $^{16}$ pelaksanaan dan penyelenggaan penegakan hukum pidana melibatkan badanbadan yang masing-masing memiliki fungsi sendiri-sendiri. Badan-badan tersebut yaitu kepolisian, kejaksaan, pengadilan dan lembaga pemasyarakatan. Dalam kerangka kerja sistematik ini tindakan badan yang satu akan berpengaruh pada badan yang lainnya.

Dan dalam hal sistem peradilan pidana ada dua model yaitu crime control model dan due process model: Crime control model

13 Tatang M. Arimin, Pokok-pokok Teori Sistem, RadjaGrafindo Persada, Jakarta, 2001, hlm. 9.

14 Wayan P. Wijaya Kusuma, Sistem Peradilan Pidana di Indonesia, Posting 11 November 2009, www.google. com, diakses 1 Juni 2013, pukul 10.15 WIB.

15 Ibid.

16 Andi Hamzah, Hukum Acara Pidana Indonesia, Edisi Kedua, Sinar Grafika, Jakarta, 2008, hlm. 33. 
merupakan model peradilan pidana yang bertujuan untuk menekan angka kejahatan dengan memberikan toleransi yang kecil, disini fungsi peradilan pidana adalah untuk mengontrol dan mengawasi. Kelemahan dalam model ini, bila terdapat ketidakmampuan komponen-komponen dalam sistem peradilan pidana dapat menimbulkan runtuhnya ketertiban umum yang mengarah pada hilangnya ketenangan sosial yang penting bagi kebebasan manusia. Proses peradilan yang terdapat dalam model ini cenderung cepat dan efisien, penekanan lebih ditekankan pada kecepatan dan penyelesaiannya. Dalam model peradilan pidana ini asas yang berlaku adalah asa praduga bersalah, dimana timbul dalam sistem peradilan pidana yang mempunyai prinsip pembuktian secara ekstensif dan professional, oleh karena itu setiap tersangka yang tertangkap dan telah dikenakan suatu tuduhan maka ia pasti bersalah.

Model peradilan pidana kedua yakni due process model merupakan model yang berbeda dengan model peradilan pidana crime control, dalam model ini asas yang digunakan merupakan asas praduga tak bersalah. Tujuan utama dari sistem peradilan dengan model ini adalah sebisa mungkin memberikan perlindungan baik itu kepada pihak yang tidak bersalah dan memberikan pidana kepada yang bersalah. Sistem peradilan ini mendapat kritikan karena dianggap terlalu melindungi hak tersangka, sebab hal ini berkaitan dengan asas yang digunakannya yaitu asas praduga tidak bersalah. Dengan berdasarkan asas praduga tak bersalah maka bentuk yang peradilan yang terdapat dalam model ini lebih merupakan menguntungkan bagi terdakwa. Pentingnya bantuan hukum pada due process model sesuai tujuan sistem ini yaitu bagaimana sistem harus bekerja sesuai dengan gagasangagasan atau sifat yang ada dalam aturan hukum. Hal ini meliputi prinsip-prinsip tentang hak-hak terdakwa, asas praduga tidak bersalah, hak terdakwa untuk diadili secara adil, persamaan di depan hukum dan peradilan. Aplikasi atau penegakan hukum pidana yang tersedia tersebut dilaksanakan oleh instrumeninstrumen yang diberi wewenang oleh undangundang untuk melaksanakan kewenangan dan kekuasaannya masing-masing dan harus dilakukan dalam suatu upaya yang sistematis untuk dapat mencapai tujuannya. Upaya yang sistematis ini dilakukan dengan mempergunakan segenap unsur yang terlibat di dalamnya sebagai suatu kesatuan dan saling berhubungan (interelasi), serta saling mempengaruhi satu sama lain. ${ }^{17}$

Oleh karena itu, setiap aparat dari sistem peradilan pidana (criminal justice system) harus selalu mengikuti perkembangan dari setiap perundang-undangan yang terbit karena aparat dalam sistem peradilan pidana tersebut "menyandarkan" profesinya pada hukum pidana dalam upaya mengantisipasi kejahatan yang terjadi. Sistem Peradilan Pidana ini 
diwujudkan/diimplementasikan dalam (empat) sub sistem.

\section{Kekuasaan Penyidikan oleh Penyidik}

Berdasarkan Kitab Undang-undang Hukum Acara Pidana (KUHAP) Pasal 1 angka 1, yang dimaksud dengan Penyidik adalah "Pejabat Polisi Negara Republik Indonesia atau Pejabat Pegawai Negeri Sipil (PPNS) tertentu yang diberi wewenang khusus oleh undang-undang untuk melakukan penyidikan”. Dengan demikian, secara umum yang diberi kewenangan untuk melakukan penyidikan suatu tindak pidana adalah Kepolisian Republik Indonesia (POLRI), namun untuk tindak pidana tertentu ada juga lembaga lain yang diberi kewenangan untuk melakukan penyidikan, seperti:

1. Kejaksaan untuk Tindak Pidana Korupsi dan Tindak Pidana HAM;

2. Aparat Dirjen Pajak untuk Tindak Pidana Perpajakan;

3. Aparat Bea Cukai untuk Tindak Pidana Kepabeanan;

4. Aparat Kehutanan untuk Tindak Pidana Kehutanan.

\section{E. Kekuasaan Penuntutan oleh Penuntut Umum}

Apabila dalam Kekuasaan Penyidikan, terdapat beberapa lembaga yang dapat melakukan penyidikan, maka dalam menjalankan kekuasaan penuntutan hanya satu lembaga yang berwenang melaksanakan yaitu lembaga Kejaksaan Republik Indonesia.
Hal tersebut tertuang dalam Ketentuan Umum KUHAP angka 6 dan angka 7 serta tercantum pula dalam Undang-undang Nomor 16 Tahun 2004 tentang Kejaksaan Republik Indonesia pada Pasal 2 ayat (1) yang menyebutkan bahwa: "Kejaksaan Republik Indonesia yang selanjutnya dalam undang-undang ini disebut kejaksaan adalah lembaga pemerintahan yang melaksanakan kekuasaan negara di bidang penuntutan serta kewenangan lain berdasarkan undang-undang".

\section{F. Kekuasaan Mengadili dan Menjatuhkan Putusan oleh Badan Pengadilan}

Kekuasaan mengadili sebagaimana diatur dalam Pasal 1 ayat (9) KUHAP adalah: "Serangkaian tindakan hakim untuk menerima, memeriksa dan memutus perkara pidana berdasarkan asas bebas, jujur dan tidak memihak di sidang pengadilan dalam hal dan menurut cara yang diatur dalam undangundang ini”. Selanjutnya berdasarkan Pasal 1 Ayat (8) KUHAP, yang diberi wewenang ini adalah "hakim sebagai Pejabat Peradilan negara yang diberi wewenang oleh undangundang untuk mengadili”.

Dengan demikian dalam proses penegakan hukum pidana, unsur-unsur sistem peradilan pidana meliputi: Kepolisian, Kejaksaan, Pengadilan dan Lembaga Pemasyarakatan. Keempat unsur inilah yang merupakan sub-sistem dari sistem peradilan pidana, sehingga keberhasilan upaya penegakan hukum sangat dipengaruhi oleh keterkaitan dan ketergantungan keempat unsur tersebut. 
Oleh karena itu, yang dimaksud dengan sistem peradilan pidana dapat juga dikatakan sebagai sistem pengendalian kejahatan yang terdiri dari lembaga-lembaga Kepolisian, Kejaksaan, Pengadilan dan Pemasyarakatan terpidana. ${ }^{18}$ Masalah bantuan hukum sesungguhnya adalah masalah klasik. Masyarakat miskin telah lama berharap akan adanya suatu proses peradilan yang adil yang dapat diakses oleh setiap warga negara. Adanya pengaturan mengenai pemberian bantuan hukum secara kongkret, dapat mengakomodir kepentingan hak-hak tersangka/terdakwa dalam proses pemeriksaan pidana. Namun, faktanya aturan yang lahir hanyalah aturan yang lemah dan penegakkannya belum sepenuhnya diimplementasikan, sehingga tidak memiliki arti penting dalam mewujudkan pemenuhan hak asasi tersangka-terdakwa untuk dapat memperoleh peradilan yang adil dan akses kepada keadilan.

Banyak kasus pidana pada waktu pemeriksaan baik pada tahap penyidikan, penuntutan dan pemeriksaan sidang pengadilan, tersangka/terdakwa tidak diberikan hak untuk mendapatkan bantuan hukum, sehingga kasus penganiayaan/ penyiksaan terhadap tahanan sering sekali terjadi. Terdakwa yang pada saat pemeriksaan di pengadilan juga tidak didampingi penasihat hukum oleh karena ketidakmampuannya untuk menghadirkan dan menggunakan jasa penasihat hukum, sehingga berdampak pada situasi yang merugikan terdakwa berupa perlakuan sewenang-wenang oleh jaksa dan hakim. Bahkan terkadang hakim justru menjadi jaksa penuntut, dimana pada saat pemeriksaan hakim justru over acting dengan tidak bersikap objektif, tetapi terus menerus menuduh terdakwa.

Kondisi demikian, juga terjadi di wilayah hukum Kabupaten Katingan, pelaksanaan pemenuhan hak mendapatkan bantuan hukum bagi terdakwa tindak pidana pertambangan pada proses penuntutan belum sepenuhnya dilakukan dengan baik. ${ }^{19}$ Untuk mengetahui lebih lanjut hal tersebut, maka dalam tulisan ini akan mengkaji melalui kegiatan penelitian baik pada jaksa, hakim, dan penyebaran quisioner kepada 5 (lima) orang pelaku tindak pidana pertambangan sebagai responden yang perkaranya sudah diputus oleh pengadilan dan berkekuatan hukum tetap.

Yang tercatat dalam data yang sudah dihimpun antara lain jumlah yang di dampingi tidak ada sama sekali berbanding dengan jumlah yang tidak didampingi 5 dari besaran presentase populasi yang kami sesuaikan dengan sampel adalah 100\%. Dalam sampel yang kami golongan dari besaran populasi jaksa 3 orang, hakim 3 orang, terdakwa 5 orang. Selain itu, di lapangan terdapat 2 orang yang diberitahukan dan 3 orang yang tidak diberitahukan presentase pada populasi

18 Mardjono Reksodiputro, Sistem Peradilan Pidana di Indonesia, Pidato Pengukuhan Guru Besar Tetap dalam Ilmu Hukum pada Fakultas Hukum Universitas Indonesia, UI, Jakarta, 1993, hlm. 1.

19 Wawancara dengan Samsuri, Kepala Seksi Tindak Pidana Umum pada Kejaksaan Negeri Katingan, Tanggal 11 Juni 2013 
adalah $40 \% / 60 \%$.

Data di atas menunjukkan bahwa: ternyata $100 \%$ responden mengaku tidak didampingi penasehat hukum. Hal ini dikarenakan pelaku tidak diberitahukan haknya oleh penuntut umum (berdasarkan data di atas, 60 responden mengaku tidak diberitahukan dan 40\% mengaku diberitahukan). Atas kondisi demikian, tentu disebabkan oleh berbagai faktor baik itu faktor intern (dari terdakwa sendiri) dan faktor ekstern (dari penuntut umum dan Institusi Kejaksaan) yang menjadi penyebab tidak semua terdakwa di dampingi pengacara atau pembela dalam proses pemeriksaan. Untuk jelasnya, faktor-faktor tersebut dapat diuraikan sebagai berikut:

1. Faktor Intern: ketidaktahuan terdakwa akan hak-haknya yang telah diberikan oleh undang-undang (hal ini dilatarbelakangi karena kurangnya tingkat pengetahuan dan pemahaman terdakwa terkait dengan hak-haknya); keinginan para terdakwa yang tidak mau/menolak didampingi walaupun sudah diberitahukan oleh penuntut umum (penolakan oleh terdakwa dikarena khawatir akan dikenakan biaya, sebagian besar terdakwa pasrah terhadap perbuatan yang dilakukannya dan juga terdakwa menganggap dengan didampingi penasehat hukum akan memakan waktu yang lama);

2. Faktor Ekstern: Pelaksanaan bantuan hukum secara cuma-cuma bagi masyarakat yang tidak mampu pada instansi Kejaksaan Negeri Kasongan tidak tersedia anggarannya; minimnya jumlah penasehat hukum (advokat), bahkan pengacara yang berkantor di wilayah hukum Kabupaten Katingan tidak ada, menyebabkan pemberian bantuan hukum kurang optimal. ${ }^{20}$

\section{Simpulan}

Di wilayah hukum Kabupaten Katingan, pelaksanaan pemenuhan hak untuk mendapatkan bantuan hukum bagi terdakwa tindak pidana pertambangan pada proses penuntutan belum sepenuhnya dilakukan dengan baik. Berdasarkan hasil penelitian, maka dapat disajikan data bahwa ternyata $100 \%$ responden mengaku tidak didampingi penasehat hukum. Hal ini dikarena pelaku tidak diberitahukan haknya oleh penuntut umum (berdasarkan data di atas, 60 responden mengaku tidak diberitahukan dan 40\% mengaku tidak diberitahukan). Atas kondisi demikian, tentu disebabkan oleh berbagai faktor baik itu faktor intern (dari para terdakwa sendiri) dan faktor ekstern dari penuntut umum yang menjadi penyebab tidak semua terdakwa didampingi pengacara atau pembela dalam proses pemeriksaan.

Dengan tidak adanya pendampingan bantuan hukum oleh pengacara atau advokat yang mendampingi terdakwa dalam tahap 
penuntutan, pengaruhnya bagi terdakwa tidak didapatkan, sehingga akan merugikan adalah bahwa hak-hak terdakwa dalam hak-hak terdakwa.

memperoleh bantuan hukum tidak ada atau

\section{DAFTAR PUSTAKA}

\section{Buku}

Altidjo Alkostar, 2004, Pengadilan HAM

Indonesia dan Peradaban, Pusham

UII, Yogyakarta.

Andi Hamzah, 2008, Hukum Acara Pidana

Indonesia, Edisi Kedua, Sinar Grafika, Jakarta.

Barda Nawawi Arief, 2001, Masalah

Penegakan Hukum dan Kebijakan

Penanggulangan Kejahatan, Citra

Adtya Bakti, Bandung.

Irfan Fachruddin, 2004, Pengawasan

Peradilan Administrasi terhadap

Tindakan Pemerintah, Alumni,

Bandung.

Leah Levin, Tanpa Tahun, Hak-hak Asasi

Manusia Tanya Jawab, Pradnya

Paramita, Jakarta.

Masyhur Effendi, 1993, Hak Asasi Manusia

dalam Hukum Nasional dan

Internasional, Ghalia Indonesia,

Jakarta.

Muhammad Yamin, 1982, Proklamasi

dan Konstitusi Indonesia, Ghalia

Indonesia, Jakarta.

Notohamidjojo, 1970, Makna Negara

Hukum, Badan Penerbit Kristen,

Jakarta.
Pendapat Jack Donelly dalam George Clark (Executive Editor), 1998, Hak Asasi Manusia Sebuah Pengantar, Pustaka Sinar Harapan, Jakarta.

Safroedin Bahar, 1997, Hak Asasi Manusia, Pustaka Sinar Harapan, Jakarta.

Tatang M. Arimin, 2001, Pokok-pokok Teori Sistem, RadjaGrafindo Persada, Jakarta.

\section{Makalah}

Mardjono Reksodiputro, 1993, Sistem Peradilan Pidana di Indonesia, Pidato Pengukuhan Guru Besar tetap dalam Ilmu Hukum pada Fakultas Hukum Universitas Indonesia, Jakarta.

\section{Naskah Internet}

Diklat Teknis LAN, diposting oleh Ali Sadikin, 2013, Konsep Negara Hukum, http:// www.alisadikinwear.wordpress.com.

Wayan P. Wijaya Kusuma, Sistem Peradilan Pidana di Indonesia, www.google. com. 